The results of the research demonstrated a reasonable level of knowledge about both pieces of legislation amongst large numbers of media librarians and a smaller number of UK journalists. It also showed that there was considerable concern within the UK media regarding the proposed EC Directive. There was a fair amount of consensus amongst respondents over the major issues. It is felt that the Draft Directive would especially affect investigative journalism without offering significant safeguards to the privacy of the individual and that it would certainly involve a great deal of bureaucratic procedures which would result in information being provided extremely slowly. There is also the likelihood that as enforcing it would be impossible people will choose to disregard it.

If the Draft Directive were implemented in this form it would have a major impact on the day to day working lives of both journalists and the librarians and information scientists who serve them.

A fuller report on this research has been published ${ }^{(1)}$.

\title{
Reference
}

1. Ellis, S and Oppenheim, C. Legal issues for information professionals. Parts III-IV. Journal of Information Science, 19, 1993.

\section{Staff appraisal in university libraries}

\author{
ANDREW GREEN \\ Library \\ University College of Swansea
}

\section{Introduction}

Staff appraisal, like the hydrogen bomb, was an American invention that emerged at the time of the Second World War. Its roots in universities lie in that monument to managerialism, the Jarratt Report, published in $1985^{(1)}$, but it only came to general notice two years later with the publication of the twentythird report of 'Committee A' of the University Authorities' Panel (UAP) and the Association of University Teachers (AUT). This agreement committed both parties to an appraisal system 'directed towards developing staff potential, assisting in the improvement of performance and enhancing career and promotion opportunities, thereby improving the performance of the institution as a whole' (2). AUT viewed the prospect of appraisal with suspicion and implementation was further delayed by AUT boycotts linked to pay campaigns.

Only one major study of the functioning of the universities' appraisal system has been published ${ }^{(3)}$, and very little has been written on the experience of libraries ${ }^{(4)}$. The purpose of this study was to shed light on the impact of appraisal on the 'old' university libraries and their staffs, s and to try to assess its benefits and disbenefits.

\section{Research methods: theory and practice}

A questionnaire was devised, tested and distributed to the librarians of all university members of SCONUL in autumn 1993. Its aim was mainly to collect factual information, but it also probed respondents' own views about the success of appraisal. Secondly, visits were paid to two libraries to 
talk in detail not only to the questionnaire respondents but also to a sample of their staffs (five individual interviewees and one group discussion).

Of 63 questionnaires sent out in September 199352 were returned completed and a further three replies received.

\section{Slow beginnings}

Not all libraries had yet adopted staff appraisal. One respondent reported that his predecessor as librarian had taken his scepticism of appraisal to such lengths that he had successfully resisted the application of his university's scheme. Owing to the difficult birth of staff appraisal nationally, it was not until 1990-91 that over 80\% of the remainder had introduced appraisal, and five libraries only began in 1992-93.

The survey asked respondents to judge the attitude of their institutions towards appraisal. All but two thought that it was either positive $(44 \%)$ or fairly positive $(52 \%)$.

\section{Appraisal for what?}

The expressed objectives of appraisal, as described by the survey respondents and the appraisal documentation they enclosed, tended to fall into a limited number of categories: improving appraisee performance, improving career development, developing promotion potential, identifying organizational barriers in the way of appraisees' development, identifying training and development needs, and improving organizational performance.

Almost everywhere a 'soft', development-centred form of appraisal was adopted. Respondents denied for the most part any links with rewards or punishments, except to the extent that in many universities it was possible that a summary of the appraisal outcome could be presented to committees dealing with applications for promotion. Attempts to judge appraisees in a literal or quantitative way are rare: only two libraries, for example, report rating systems in use in appraisal reports.

\section{How often?}

Libraries were about equally divided between those that appraised staff annually and those that appraised biennially. Some of the latter had moved to biennial frequency, having started out with an annual scheme, and some of the former were contemplating the same change.

\section{Appraisers and appraisees}

One obvious difference between academic and academic related staff is that the latter usually work within a relatively hierarchical rather than 'flat' staff management structure. It is hardly surprising, then, to find that appraisers in libraries tend to stand in a managerial relation to those whom they appraise. Most respondents said that the choice of appraiser lay with the librarian, and that the choice was governed by the principle of seniority or line management. Three libraries, however, including one visited, had a quite different system based on peer appraisal.

Only half of the institutions set a maximum limit on the number of appraisees a single person can appraise, the median maximum being six. 
An interesting point is who appraises the librarian (or equivalent), $42 \%$ of respondents identifying the Vice-Chancellor (or equivalent), a third a Deputy Vice-Chancellor (or equivalent), and the rest mentioning an assortment of others. Three respondents confessed that in reality no one appraised the librarian!

In all but one of the libraries appraisers received training in their roles from their universities. In almost half appraisees received none, though nine libraries took it upon themselves to supply training. On the other hand many universities (and some libraries) provided forestfuls of paper documentating the nature and machinery of their schemes and offering useful advice to appraisers and appraisees, for example on how to handle interviews.

\section{The appraisal process}

Typically the appraisal process consists of three phases: preparation, the interview between the appraiser and appraisee, and the writing up of a report or record.

Preparation, according to the respondents, averages about 50 minutes. The appraiser often has the task of summarizing the purpose of appraisal, arranging an interview date and setting an agenda for discussion with the appraisee. It falls to the appraisee to refresh his or her job description, review performance since the previous appraisal and meditate on future ambitions and needs. The preparation phase is document-intensive: in addition to a preparatory or self-appraisal form (needed in $73 \%$ of libraries) the appraisee may also be expected to produce a curriculum vitae or a job description.

The interview is the core of the process. Its length can vary between 40 minutes and two and a half hours, the mean average being an hour and a half. Almost invariably it will include a discussion of progress in the past, objectives for the appraisee in the future, and training or development needs; in addition, the appraisee's job description will sometimes be reviewed, and future action will often be specified for the appraiser or organization as a whole. Most institutions, to judge from their printed guidelines, seem to aim for what one termed 'structured informality': an environment where the appraisee can feel free to talk at some length on a variety of issues, but without escaping altogether the discipline of a set agenda.

Finally, it is normally the appraiser who is responsible for writing a report or record, a task that takes on average 45 minutes. The completed report is then shown to the appraisee, who normally has a chance if necessary to record dissent or append comments. The document is then seen by the librarian (in $90 \%$ of libraries), but rarely by anyone else, although a summary of training and development needs is often forwarded to the university's staff training officer, and the report can be used in evidence in promotion applications. As well as recording training needs the report will generally refer to the appraisee's past performance and will include an action plan for the appraisee and, in three-quarters of cases, for the library or appraiser.

\section{The impact of appraisal}

Survey respondents were asked to react to a series of statements about the benefits or drawbacks of appraisal derived from a reading of published literature on the subject.

All but two respondents agreed that appraisal helped to set personal goals for appraisees, and that it also helped them to give feedback and support - 73\% thought that appraisal actually contributed to better performance and $79 \%$ considered that it had given added impetus to training and development. Rather 
fewer (44\%) believed that it helped to improve morale or job satisfaction. Another statement suggested that appraisal helped to set organizational, as opposed to personal, goals: $71 \%$ agreed.

However, even those who seemed sure about the benefits of appraisal were willing to concede that appraisal was not always taken seriously by those participating ( $40 \%$ agreed with this statement) and a smaller number (29\%) admitted that action plans tend to be forgotten once the appraisal process is over.

Despite these caveats, however, when faced with the final, general proposition that 'on balance the benefits of staff appraisal outweigh the drawbacks', 21\% strongly agreed, $73 \%$ agreed, and no one could be found to disagree, whether strongly or not.

The appraisers and appraisees in the libraries visited held more varied views. Some had derived substantial benefits from appraisal, especially in terms of 'stocktaking', feedback on past performance and the setting of personal objectives. Others regretted the lack of positive outcomes, and some would frankly have preferred a scheme directly tied to rewards.

\section{Soft appraisal or hard appraisal?}

The survey made no direct attempt to gauge respondents' views on appraisal 'flavour', but many volunteered their opinions. Many valued the 'softness' of their schemes. others, though, were less satisfied, including a radical group of seven librarians who would like to see wider use made of the outcome of appraisal, with an explicit link to annual review procedures, promotion or pay. The dilemma was summed up by one writer thus: 'I don't particularly wish it to become part of the promotion process, but unless there is some consequence of appraisal it is likely to fizzle out in a year or two as many will get bored with it. If, however, there is a link to promotion staff may 'close up' during interviews'.

\section{Appraisal extended?}

In only three libraries were all staff on all grades appraised, but a quarter had schemes for clerical and administrative staff (17\% for non-academic related professional staff, $11 \%$ for manual and $6 \%$ for technical staff). Six respondents expected an extension to other staff, and as many welcomed the prospect, although a few expressed anxiety. about the time costs.

\section{Will appraisal survive?}

On the evidence of the libraries surveyed there would seem little doubt: the perceived benefits easily outweighed the drawbacks, for appraisees as well as appraisers. However, it is not the verdict of library staff that will determine appraisal's long-term future, but the experience of academic staff. No explicit attempt was made to assess the impact of appraisal on academic staff but a consistent refrain heard during the two visits was that appraisal was often treated less seriously in academic departments. One interviewee used the phrase 'a travesty of indifference' to describe academic appraisal. This suggests a wider disaffection among academic staff that is apparent only occasionally among library staff, and that could imperil appraisal's future, especially if, as recent AUT statements clearly suggest, it is liable to be boycotted if the union's pay demands are not met ${ }^{(5)}$. It is also worth noticing that appraisal seems much less secure among higher education institutions outside the old universities: the questionnaire compiled for the Follett Report revealed that $43 \%$ of all libraries did not operate formal systems ${ }^{(6)}$. On the other hand, the movement to extend appraisal to other grades of university staff, endorsed by the Fielden report on HE library staffing, suggests that there is plenty of life left in the concept - and plenty 
of work ahead for academic libraries.

\section{References}

1. Committee of Vide-Chancellors and Principals. Steering Committee for Efficiency Studies in Universities (Chairman: Sir Alex Jarratt). Report. CVCP, 1985.

2. Universities Academic Salaries Committee. Twenty-third report from Committee A. UASC, 1987, para 43.

3. Bull, Ian. Appraisal in universities: a progress report on the introduction of appraisal into universities in the United Kingdom. CVCP Universities' Staff Development and Training Unit, 1990.

4. Almost all the literature is unpublished; see the following M.Lib theses from the Department of Information and Library Studies, University of Wales, Aberystwyth: Sarah Fitzpatrick, The development of a staff appraisal system for a small academic library (1993); Judith Anne Bater, Approaches to staff appraisal in British polytechnic libraries (1989); Katherine Ann Baird, The implementation of a staff appraisal scheme with reference to academic libraries (1990), and Margaret Elaine Hansen, Staff appraisal and training and development in British academic libraries (1994).

5. 'Why we should boycott appraisal', AUT Update, 14, 10 March 1994, p3.

6. John Fielden Consultancy. Supporting expansion: a report on human resource management in academic libraries, for the Joint Funding Councils' Libraries Review Group. HEFCE, 1993, p345 (para 4.25).

\section{Acknowledgements}

I should like to thank the Library and Information Research Group, who gave me the Daphne Clark Award in 1993 and enabled me to carry out this research project, and all the librarians who cooperated by completing questionnaires and devoting their time to answering my questions during the two visits. There can be few other professions more hospitable to being investigated by the inquisitive.

A fuller version of this paper is available from the author (email: a.m.w.green@uk.ac.swansea). 